\title{
"We Have Gone Recreation Mad": The Consumption of Leisure and Popular Entertainment in Municipal Public Parks in Early Twentieth Century Britain
}

\author{
Carole O'Reilly
}

University of Salford

This study examines the development of popular entertainment in the municipal public parks of a variety of British cities in the early decades of the twentieth century. It seeks to extend the debate about the social role of the urban park beyond the Victorian period and to challenge the idea that parks were mere mechanisms for social control. Their later developments were more complex and offered an increasing variety of popular entertainments such as dancing to a more discerning leisure consumer. In so doing, park managers found themselves in direct competition with private leisure providers and attempting to anticipate future trends in an expanding leisure population. The article concludes by considering how the determination to broaden the recreational value of the public park ultimately weakened its unique character and began a long cycle of decline.

KEYWORDS public parks, popular entertainment, citizenship, recreation, leisure, consumption

\section{Introduction}

In I92 I, the Conservative MP Sir Herbert Nield observed that the British people "have gone recreation mad" at a meeting of the Lord's Day Observation Society. ${ }^{\mathrm{I}}$ The expansion of public leisure and recreational facilities (cinemas and dance halls, for instance), especially since the end of the First World War, lent some credence to Nield's view. The development of these new forms of leisure had been influenced by a more affluent population, at least some of whom had access to paid holidays, and by the increasingly diverse uses that were being found for public open spaces such as municipal parks. Parks had always had a close association with recreation and health but the early decades of the twentieth century saw an expansion of the kinds of usages made of these open spaces and an increasing 
move away from the provision of sporting recreation towards popular entertainment. Much of this new provision was aimed at an increasingly leisure-hungry population with access to a diversity of options for their free time.

The result of this was the emergence of a tension between recreation and entertainment in the municipal park as the spaces struggled to redefine themselves in the inter-war period. This tension is the subject of this article, which sets out to examine how municipal parks evolved during the early twentieth century and the kinds of factors that determined their development. The battles about the need for open spaces for public recreation had been won during the Victorian period but the debate about how parks should be developed, maintained and funded was only beginning.

This study centres on the early twentieth century developments in municipal parks in British cities such as Leeds, Liverpool, Cardiff and Manchester. The intention is to highlight some regional patterns of the evolution of public leisure practices in these areas and to emphasise the importance of such regional distinctions. It was the case that many of the elements discussed here were also occurring in other parts of Britain but the purpose is to demonstrate that national patterns were replicated at local and regional level, albeit with some variations.

Municipal parks had begun to appear in British towns and cities since the I 840 os. Initially, their design and usage had been guided by such Victorian ideas as "rational recreation" - a blend of genteel strolling with educational possibilities offered by museums and art galleries, where parks buildings permitted these facilities. However, by the twentieth century, public parks were changing - driven by newer ideas such as active citizenship and social responsibility, the individual park user could avail themselves of a variety of sporting activities such as golf, tennis, swimming baths, orchestral music and sumbathing in the confines of a municipal park.

The tension evident between recreation and entertainment illustrates one of the problems facing municipal authorities after the First World War - how to entertain their populations and encourage a healthy lifestyle, without committing themselves to the spending of too much public money. Increasingly, local authorities had been providing entertainment in the shape of municipal theatres, but they had also looked to make use of other facilities under their control for public events. This encompassed the use of public baths for swimming galas and the staging of open-air plays in public parks. Such activities brought local authorities into direct competition with private commercial entertainment providers and resulted in a series of costly legal disputes during the I920s and I930s. Public parks became multi-functional spaces as they tried to compete with a growing variety of leisure opportunities and a more sophisticated public as consumers of leisure.

This article suggests that the relationship between recreation and entertainment that emerged in the twentieth century British public park fundamentally altered the relationship between the park and the urban landscape that surrounded it. The Victorian park had proved to be a significant element in the development of ideas about citizenship. ${ }^{2}$ The shift away from recreation to entertainment in public parks marked a move away from concerns about citizenship and the emergence 
and development of the consumer. This reflected the new primacy of entertainment in the twentieth century city.

\section{Municipal Public Parks in the Twentieth Century}

It has been suggested that citizenship in the Edwardian period was refocused away from the urban arena and onto the Empire. ${ }^{3}$ This article contests this view and demonstrates that active urban citizenship remained a potent social force in the landscape of the urban park until the inter-war period. These parks offered the opportunity to both establish and display not only a sense of civic pride in the city, but pride in the collective ownership of that space. Municipal parks, therefore, represented a place where urban citizenship could be continually forged and contested, both by park authorities and by park visitors.

A connection was established between civic pride and social citizenship in which the municipality assumed responsibility for the welfare of all citizens. The corollary of this was that the city dweller reciprocated in accepting the care of the urban environment as a part of their civic duty. Citizenship was an ambiguous term before the 1870 and encompassed potentially all of those who had a general interest in the welfare of the nation. ${ }^{4}$ From the late Victorian period, we find the model of citizenship becoming more proactive and socially aware. Rodrick's work on Birmingham emphasises a shift towards a national education system centred on children's citizenship in the early years of the twentieth century. This article builds on that work to demonstrate the continuing significance of citizenship as a concept central to the development of ideas about leisure in later decades.

The needs of the Empire were undoubtedly to become more significant as the twentieth century advanced - the use of Heaton Park as a training camp for the Manchester Regiment prior to their deployment in the First World War demonstrates that the park evolved into a space that could accommodate such imperial needs while continuing to function as a public leisure space. ${ }^{5}$ Thus, imperial, national and local citizenship could co-exist and were not mutually exclusive.

Hugh Cunningham argues that, by the end of the nineteenth century, public leisure facilities reinforced the desire for class exclusivity as a result of the appropriation of formerly aristocratic pursuits such as hunting by the middleclasses, the invention of class-specific sports like golf and tennis and the imposition of a middle-class ethos on sports such as rowing and athletics. ${ }^{6}$ While this may be difficult to prove, it does provide an explanation for the increasingly class-bound nature of leisure at the end of the nineteenth century and militated against the ideal of recreation as a tool for unifying social classes advocated in the $\mathrm{I} 84 \mathrm{O}$. It also marks the gradual refinement of ideas such as rational recreation, elements of which still persisted. Cardiff's Councillor Meyrick observed in I902 that Roath Park was "not simply for the man who wore broadcloth, not for the well-bonneted women; it was just as much for the man who lived a colourless life in the slums."7

The provision of facilities for physical exercise in municipally-owned parks was a consequence of an earlier perception of the need to maintain levels of physical fitness among the population. Exercise facilities in public parks were not 
exclusively an Edwardian idea - the three original public parks in Manchester and Salford all had gymnasia (Salford's Peel Park had archery butts). The provision of this kind of equipment was an acknowledgement that parks were not simply open spaces for polite perambulations, but had a more pragmatic purpose. Ann Rodrick has argued that the Victorians tended to see leisure time as a contrast to idleness and as a valuable entity that should not be wasted. ${ }^{8}$ In the twentieth century, leisure took on a more complex meaning, tailored to the needs of the individual consumer.

The role of the urban park in the whole civic landscape was also now being considered. Liverpool City Council proposed the idea of creating a ribbon of parks around the city as early as I 850 but it lacked the necessary powers to raise the money to fund the scheme. ${ }^{9}$ The operation was partially realised between 1868 and 1872 with the creation of Newsham, Stanley and Sefton Parks to the north, east and south of the city. ${ }^{\text {IO }}$ A similar idea was proposed for London by the Tory MP W.J. Bull in I90I. Bull suggested buying land adjoining London's parks to create a "green girdle" that would run around the perimeter of the city. ${ }^{\text {II }}$ F.J. Holmes writing in The Quiver suggested extending this idea in other British cities such as Newcastle and Sheffield to create a "glorious girdle of rurality." ${ }^{2}$ Few of these suggestions were realised, but they are indicative of a new twentieth century way of conceiving of the function of the park in the city as a whole and not merely as a contrast to it (notwithstanding Holmes's reference to "rurality"). This element is also observable in other European cities such as Zagreb, where attempts were made to establish a "green horseshoe" of parks, framing the lower town on three sides and modelled on the Ringstrasse in Vienna. ${ }^{\text {I3 }}$

In I904, Manchester City Council built its first municipal housing estate in Blackley near Heaton Park and subsequently developed Wythenshawe Garden City around Wythenshawe Park during the I930s. ${ }^{\text {I4 }}$ Thus, the public parks helped to contribute to the development of desirable neighbourhoods where people wanted to live, but not in wealthy seclusion.

Such attempts at social integration produced a new understanding of social democracy that emphasised the idea of the urban community and good citizenship. ${ }^{15}$ This vision of democracy was defined by the harmony between nature and the individual and one that worked to idealise the past and improve on the present. The idea reached its artistic high point in the garden city movement of Raymond Unwin, Barry Parker and Ebenezer Howard during the early years of the twentieth century. The garden city was specifically designed to merge the country and the city and to encourage communal activities such as tennis and bowling. Here, amenities were a right not a privilege and their proper use was a cornerstone of good citizenship. ${ }^{\mathrm{I} 6}$

This progression from Victorian moralism to Edwardian pragmatism was, perhaps, a logical one that resulted in the beginnings of a practical approach to town and urban planning. This, coupled with more public demand for leisure due to an increase in holidays for workers, necessitated a more professional approach to municipal leisure management and, therefore, a more important role for public park managers (or General Superintendents, as they were known). A move towards citizens exercising some of their own responsibility (however loosely 


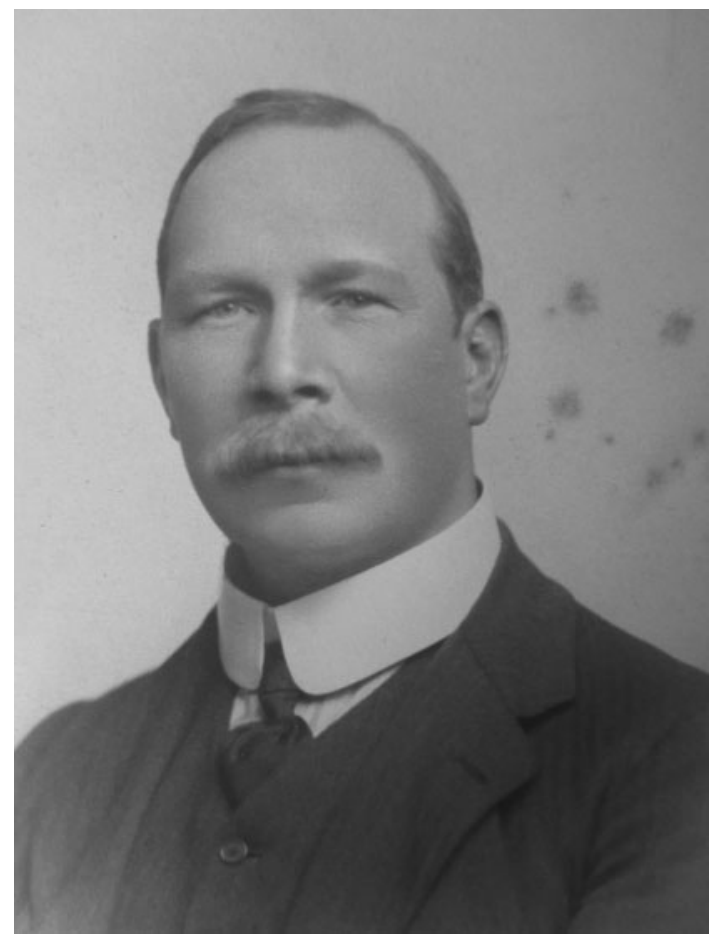

FIgURe 1 William Wallace Pettigrew, 1915 @ Tim Pettigrew, Pettigrew family archive

defined) for the protection of parks, coupled with a decline in the authority of the park keeper, resulted in the rise of the professional parks administrator or superintendent. Such managers usually came from a horticultural or design background rather than administration. Edward Kemp, parks superintendent in Birkenhead from I 843 designed Grosvenor Park in Chester and Queen's Park in Crewe. ${ }^{17}$ One of the most prominent and influential British parks superintendents was William Wallace Pettigrew (I867-I947), General Superintendent of Parks in Cardiff (I89I-I9I5) and Manchester (I9I5-I932), whose father and brother, Andrew also worked in this capacity (see Figure $\mathrm{I}) .^{\mathrm{I} 8}$

The early decades of the twentieth century were suffused with ideas of active citizenship, which included a commitment to good physical and moral health. ${ }^{19} \mathrm{~A}$ healthy citizenry contributed to a healthy nation and formed the building block of a well-ordered society. ${ }^{20}$ The environment of a public park could offer the opportunity to develop not just physical health, but a sense of public-spiritedness and civic identity. This can be seen in the use of public parks by the Boy Scout movement, one of whose primary aims was the development of citizenship skills. ${ }^{2 I}$ These activities were connected to emergent ideas about citizenship and collective responsibility for one's surroundings - a substantial move away from the Victorian idea of parks as patrolled by park keepers and attendants who bore sole responsibility for the park's upkeep and maintenance.

In part, many of the decisions about how to develop public parks were a reflection of a broadening definition of public health, away from specific matters 


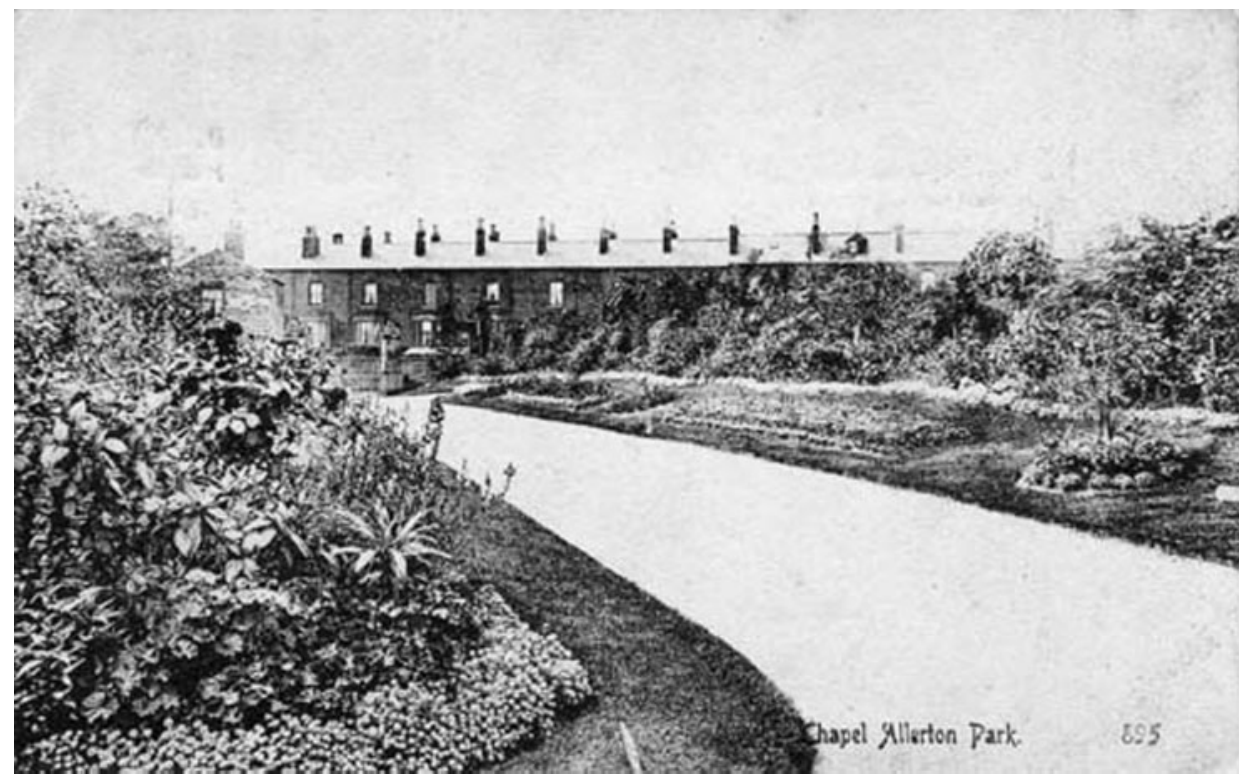

FIGURE 2 Chapel Allerton Park, Leeds 1906 ( ) From the collections of Artemis, Leeds Museums Service

such as sanitation and slum removal and towards issues such as recreation and physical fitness. This manifested itself in organisations like the Manchester Physical Health Culture Society and Leeds's Everywoman's Health Movement, devoted to promoting outdoor sports and physical development. Public parks offered a location where the city and the citizen could thus develop in tandem - to "become a self-governing member of a self-governed community." 22 This emphasis on the community and the explicit link between health and well-being marks a transition from the Victorian middle-class moral imperialism of rational recreation to a more general concern with the health of the population as a whole.

The idea of the community was gradually expanded in the early decades of the twentieth century to include the recreational needs of women and children. By this time, many local authorities began to acquire smaller parcels of land, often in overcrowded areas to be developed as recreation grounds (or playgrounds). These spaces did not offer the facilities of the larger parks but were intended to ameliorate the drab streets and to provide basic recreational environments for deprived children. Leeds City Council began to develop such spaces from I905, often taking over plots of land from charities and trusts. ${ }^{23}$ Chapel Allerton Park was a mere 6.5 acres and was located close to an estate of terraced houses (see Figure 2). Similarly, Cardiff acquired such children's playgrounds from I908. ${ }^{24}$ These spaces were conceived of as an alternative to children aimlessly hanging around on the streets and demonstrate the continuing belief that open space was preferable to urban streets and lanes.

Many of these recreation grounds were small in size, concreted over and contained basic exercise equipment such as swings and seesaws. An official guide 
to parks in Leeds commented that their intention was to be used by children "instead of being left to infest the street corners of the district." ${ }^{25}$ The idea of the children of the urban poor as an infestation has connotations of disease and infection and serves as a reminder that the poor were perceived as having different, and often quite separate, recreational requirements. This was akin to the place accorded to women in parks.

The presence of women in public spaces such as parks had been prized by the Victorians as women were believed to be positive role models who encouraged good behaviour in others. Contemporary photographs suggest that municipal parks were popular with women in the early twentieth century but due consideration of their specific recreational needs was not a priority at this time. Participation in such sporting activities as cycling was regarded as unladylike, leading women to be welcomed in public parks more for their stabilising influence than their ability to make active use of the facilities. ${ }^{26}$ However, this situation did not persist in the longer term, mainly due to women's desire to actively participate in sports such as tennis and to the growing acceptance of at least some sports as permissible for women, notwithstanding the constraints of time and money. ${ }^{27}$

In I9 I 5, William Wallace Pettigrew was invited by the Lancashire and Cheshire committee for the employment of women to establish a training scheme in horticulture in public parks for the duration of the war. ${ }^{28}$ Such training schemes were not unusual for young men but this was the first time such opportunities had been aimed specifically at women. Six women were being trained at Heaton Park in September and Pettigrew reported great interest in the project from the local newspapers who had been asking for photographs of the trainees, underlining the novelty of the enterprise. ${ }^{29}$ The specially- designed syllabus, overseen by Pettigrew had resulted in the women being "thoroughly in earnest and taking quite an interest in the work." 30

The training scheme continued throughout the war years and resulted in many of the trainees successfully completing the course and gaining employment in parks around the country. Similar initiatives were replicated in many British public parks for the duration of the war. ${ }^{3 \text { I }}$ Some cities, however, such as Cardiff, did not employ any women in this capacity at all. ${ }^{32}$ The Manchester scheme ceased after the war, however, suggesting that such initiatives were regarded as a temporary war-time aberration and not a long-term commitment to the training of women in horticulture.

While the recreational needs of groups such as women were slow to be recognised in their own right, the impetus of the public parks movement changed from the Victorian rational recreation to Edwardian foregrounding of the active citizen. While this made public parks potentially more democratic and inclusive spaces, it also raised questions about the future developments of these parks in the context of the wider city. The emergence and popularity of private commercial forms of entertainment such as music halls and cinemas meant increasing pressure on public parks to compete as part of a general regimen of public health and leisure activities. 


\section{Popular Entertainment in Twentieth Century Public Parks}

In 1926 at the Theatrical Managers' Association (TMA) annual lunch in London, the organisation's President Tom Buffen Davies opined that one of the major dangers to the future of theatres was an attempt by municipalities to enter the entertainment business. ${ }^{33}$

Parks were competing against a thriving private leisure and entertainment industry for the attention of an increasingly time-rich and whimsical public. They were attempting to appeal to a broader range of people and determined efforts were made to develop new facilities that kept up with a public that had become used to an increasingly commercialised form of leisure. Public parks were a municipal facility, publicly funded, and frequently, loss-making. In Manchester, for example, 47 public parks brought in a total of $£_{7,792}$ in 1908 , but cost $£_{35,575}$. Similarly, Cardiff's municipal parks cost $£_{\mathrm{I} 5}, \mathrm{IO} 6$ to run in I907. ${ }^{34}$ In I9I3, with the numbers of parks in Manchester now at 6I, the revenues were $£_{\text {I2,OI } 6}$ and expenditure was $£_{46,70 \text { I. }}{ }^{35}$ Thus, expenditure generally ran considerably ahead of income in the municipal public park, causing pressure within the municipal authorities to find new ways of maximising revenue.

However, this expense was often justified by reference to the broader benefits resulting from the provision of such public spaces. William Pettigrew, reflecting on his years of employment in Cardiff and Manchester, wrote that "broad-minded, far-seeing public authorities appreciate that the real assets derived from the provision of all pastimes in their parks are not monetary in character, but are the enhanced health and happiness of the community." 36

Gradually, the Victorian moral imperialism of rational recreation was replaced by the idea of leisure - a right, not a privilege and one that was increasingly taken up by people according to their means. Popular entertainment refers to that which is enjoyable and for which there is demonstrable demand. ${ }^{37}$ Both the production and consumption of leisure accelerated during the inter-war years with theatres, cinemas and dance halls flourishing. In some cities, this had begun at quite an early stage. Leeds Town Topics, a weekly magazine devoted to popular entertainment, especially the theatre, regularly included references to musical performances in Leeds parks from I9 10. ${ }^{38}$ Parks visitors were encouraged to view public parks as places of popular entertainment and not just for recreational purposes. The Victorian didactic element decreased, along with the early twentieth century emphasis on citizenship, emblematic of the shift from recreation to entertainment. Many of the newer popular entertainments included costume concert (or "Pierrot") parties and dancing in parks and were designed to appeal to a broader demographic. William Wallace Pettigrew researched these activities using his contacts in park administration in other cities such as Birmingham, Liverpool and Glasgow, where he studied the appeal of public dancing in parks in 1920. ${ }^{39}$

After the First World War, Britain's public parks moved into a new phase of their existence, one which sought to extend their popularity and to provide entertainment for the masses, rather than the elite sporting activities such as golf and tennis. Costume concert parties, choir concerts and orchestral performances were introduced to cater for those whose musical tastes went beyond that generally provided by the brass and military bands that played in the parks. Connections 
were emphasised between listening to music in the open air and a healthy lifestyle. Commenting on the difference between open-air musical performances and those of the music hall, Pettigrew argued that "it is much better that people who prefer a light type of music should be encouraged to seek it in the open air rather than find it in music halls, where the surroundings are not always conducive to the most vigorous health." ${ }^{\circ}$ The lightness of the style of music complemented the fresh air of the park and both are identified as important components of public health.

The introduction of dancing and costume concert parties was an opportunity to capitalise on the long-established popularity of music in public parks. Music had been one of the earliest forms of park entertainments, firmly connected to the Victorian belief in its didactic and cultural power. ${ }^{4 \mathrm{I}}$ While the earliest musical performances in public parks concentrated on brass bands, there was now an attempt to widen the genres of music played and the appeal of this particular entertainment. Many local authorities such as Cardiff and Manchester appointed a professional musical director to oversee the selection of bands and types of music to raise standards and to provide a wider variety of musical experiences. The musical director's responsibility was not simply to ensure the quality of the music being played but to extend the range of music beyond that of the brass and military band and to incorporate orchestral music.

Some parks were late to discover and provide for musical entertainments. Glasgow's Kelvingrove Park only opened its bandstand and amphitheatre in 1925 but soon attracted more than 6,000 people to its twice-weekly musical performances. Furthermore, these performances were often broadcast on BBC Radio Scotland as part of a popular programme entitled Scotland Calling. ${ }^{42}$

Some forms of popular entertainment in municipal parks were less welcome than others. Gambling, for so long a persistent problem in the Victorian park, continued to be a regular feature of many twentieth century parks. This was especially apparent when the parks in question had buildings that could be used for this purpose. A building known as the Queen's Park Parliament (provided for local parks visitors to hold impromptu discussions) in Queen's Park, Harpurhey, Manchester was still being used for gambling in the late I920s, despite the provision of notices warning people of its impropriety. ${ }^{43}$

The increasing emphasis in many public parks was the importance of establishing popular entertainments at regular times and on consistent days of the week. This sought to encourage park visitors to make their attendance a regularly, planned-for event. This was, in part, a reflection of the increasing amount of leisure time and an increasing variety of leisure activities on offer, especially in urban areas. A broad menu of possible recreational facilities was to be offered in each municipal park, allowing the user to choose their own patterns of consumption.

Many popular entertainments offered during this period were subject to the whims and fads of the audience. Dancing in public parks, so popular an activity on its introduction in I920, waned in popularity later in the decade, due to the lack of public demand and its often weather-dependent nature. Other popular entertainments in parks were more successful - the introduction of open-air plays staged by the Manchester Repertory Company in 1935 was immediately successful. The 
plays were generally drawn from the classics - Antony and Cleopatra and The Trojan Women and were often staged twice daily during the summer months. ${ }^{44}$

During his time in Cardiff, Pettigrew had been opposed to the introduction of private tenancies into the public parks. In a policy document submitted in 1908 , he argued that "money-making interests" conflicted with the needs of ordinary park visitors. ${ }^{45}$ However, such interests had now become an integral part of commercial activities in parks and were an important, if often transient, source of funds for future developments. The development of such commercial activities in the parks illustrates the tensions now evident between the recreational and entertainment usages of these urban spaces. The pressure was on to maximise the revenues from public parks and offering many different kinds of entertainment represented an important opportunity to be exploited. Many municipal authorities were becoming more active in the provision of entertainment more generally and were re-orienting themselves towards a consumption-driven public.

During the I920s and I930s, the Theatrical Managers' Association (an organisation formed in 1894 to protect the interests of London and provincial theatre managers) and the Entertainment Protection Association (EPA, representing variety theatres and music halls) undertook a series of legal actions designed to prevent municipal authorities using money from the rates to fund theatrical productions and to build municipal theatres. The provisions of the Public Health Act (I925) gave powers to local authorities to use any public park or municipal pleasure ground for the purposes of concerts and entertainment. ${ }^{46}$ The TMA took part in a series of legal actions nationally to "preserve the principle of preventing municipal trading against private enterprise." 47

In response, many municipal authorities enacted their own legislation to give them powers to use public money to fund entertainment in environments such as public parks. The Cardiff Corporation Act of 1930 hoped to deal with the shortcomings of the Public Health Act (1925) in respect of not permitting the municipality to pay for parks entertainments such as costume concert parties. The TMA's opposition to this bill and a similar one in Hull cost the organisation $£_{357 .{ }^{48}}$ The bill, once enacted, allowed Cardiff Corporation to arrange and to pay for concerts, exhibitions and other entertainment by amateur groups and to erect buildings on any land they owned in connection with the provision of entertainment - pavilions, bandstands and assembly rooms, for example. ${ }^{49}$

The TMA also took action against municipal authorities who planned to stage open-air plays in public parks. Both Wallasey Corporation and Luton Town Council began to offer that form of entertainment in their public parks in 1935 . Wallasey defended its action by using the Public Health Act of I890, which allowed the closure of part of any public park for not more than four consecutive days for any public purpose. ${ }^{\circ}$ TMA sought intervention from the Ministry of Health but their response was unequivocal..$^{5}$ In the case of Luton's Wardown Park, the Town Council pointed out that they were only charging $£_{5}$ a week for the Bragg-Liddell Touring Company to use a specially designed part of the park for open-air performances. The TMA attempted to argue that even such a small sum meant that other theatre companies would have to charge less to remain 
competitive with the park. ${ }^{52}$ Luton Town Council responded that they believed that the town could "stand two shows at one and the same time." 53

This type of defence demonstrates the significance of such ventures to these municipalities and their belief that they had the legal powers to provide them. For the most part, these authorities were using parts of their parks that were already designated for this purpose and were, therefore, lawful. Many TMA campaigns were already too late to prevent this kind of activity taking place, especially in the open-air, as the TMA themselves acknowledged. ${ }^{54}$

The implication of the move toward entertainment in public parks was to bring them into direct competition, not just with theatres, music halls and private commercial pleasure grounds such as Manchester's Belle Vue, but also with the growing popular entertainment of cinema. By 1935, the TMA was declaring that annual theatre revenues were being reduced and that "more and more theatres were going over to cinemas or closing down and touring companies were becoming fewer and fewer." 55

The evident tensions between recreation and entertainment and the right of local authorities to provide facilities for both illustrate much about the idea of public leisure during this period. The fears of TMA members are best explained by the rising popularity of entertainments such as cinema and the declining appeal of provincial theatre during this period. There was also the concern that municipalities that provided forms of variety entertainment would expand their provision into municipal theatres. ${ }^{56}$ This would have meant subsidised competition for already-struggling provincial theatres, with municipalities paying for this out of the rates. While the provision of municipal recreation spaces and facilities had traditionally been accepted, the extension into entertainment was creating conflict. In part, this was due to the emergence of new ideas about public health, the body and the consumption of leisure time.

\section{Healthy Cities, Healthy Citizens}

The introduction of the 1925 Public Health Act indicated a further move towards the possibility of using parks to produce revenue from leisure and entertainment activities. The Act enabled local authorities to rent out portions of public parks to local cricket and football clubs and to charge the public for admission to watch matches. ${ }^{57}$ Restrictions continued to be placed on the use of public parks for the purposes of entertainment. Costume concert parties were not legalised by the Act, thus depriving many parks authorities of a reliable and popular form of income and preventing the staging of plays that required costumes and scenery.

What is clear is that, post-war, there emerged a new emphasis on health and fitness and on body image that was to have consequences for the urban park. The body began to be perceived as capable of improvement and physical perfection. A healthy and fit body was a hallmark of a good citizen and central to one's civic duty. ${ }^{58}$ Thus, the definition of citizenship became restricted to an association with physical health. Commenting on the popularity of the open-air baths in parks, the Manchester Guardian observed that the water at the baths at St George's recreation ground in Hulme was "swarming with vigorous young bodies which, 
but for its existence, would probably have been lounging about the dreary adjoining narrow streets." 59 Moreover, a healthy body made for a happy disposition in the individual. This was reinforced by the 1937 Physical Training and Recreation Act, which enabled the creation of physical training centres in cities. Many municipal authorities, such as Manchester City Council, undertook to build physical training centres in the city's parks that included gyms, drill halls and physical culture rooms.

While this was an extension of the Boer war era anxiety about the physical condition of the working classes, it was also indicative of a new movement that emphasised the importance of physical exercise for all. Associations such as the Women's League of Health and Beauty were formed and quickly became popular, especially with working women. The Manchester branch had a membership of 3,050 in 1936 and incorporated fitness classes with other pastimes such as dancing. ${ }^{60}$ Physical exertion of the body was becoming an important health indicator and also a significant part of consuming leisure opportunities. Group exercising allowed individuals to promote themselves as healthy, attractive and publicly visible as such. This view of citizenship also emphasised the importance of place and locality. Citizenship was not just expressed at imperial or national level but within the confines of a particular town or city.

The acquisition of large-scale land for public parks remained a goal of many municipal authorities during the early decades of the twentieth century Manchester City Council received the donation of the 250-acre Wythenshawe Park from Ernest and Shena Simon in 1926, which inspired the development of a garden city suburb in that part of the city. ${ }^{6 \mathrm{I}}$ But the emphasis also began to change in favour of the addition of smaller parcels of land, often referred to as recreation grounds and frequently located in inner city areas that had previously been overlooked as far as the provision of open space.

These were often acquired with the needs of working class children in mind and imaginative steps were taken to take advantage of even the smallest of spaces. Cardiff Corporation acquired the tenancy of Tyndall Street playground in a congested area of the city in I92I. While some supervision of the playground was attempted by priests from an adjoining church, the chains were stolen from a giant stride (a telegraph pole with ropes attached that rotated and lifted one off the ground) that had been donated by a local councillor and the tenancy was eventually terminated in $1926 .{ }^{62}$

Cardiff Corporation acquired the two acres of Waungron Common as a recreation ground in I923. It was improved by the Parks committee with the addition of hedges, fences and trees and reserved for young children only. ${ }^{63}$ The $\mathrm{I} \cdot 75$ acres of Ely recreation ground was acquired in 1926 and equipped with hard tennis courts and a bowling green. The opening ceremony was performed by the chair of the Parks Committee serving a tennis ball on one of the courts. ${ }^{64}$ Manchester City Council demolished St John's Church in the city centre in I93 I to provide a children's playground (see Figure 3). ${ }^{65}$ Stanley Park in Liverpool opened a children's garden in 1926 which contained statues inspired by popular children's stories. Sefton Park erected a statue of Peter Pan in I929 and made available a series of life-size pirate ships on which children could play. ${ }^{66}$ 


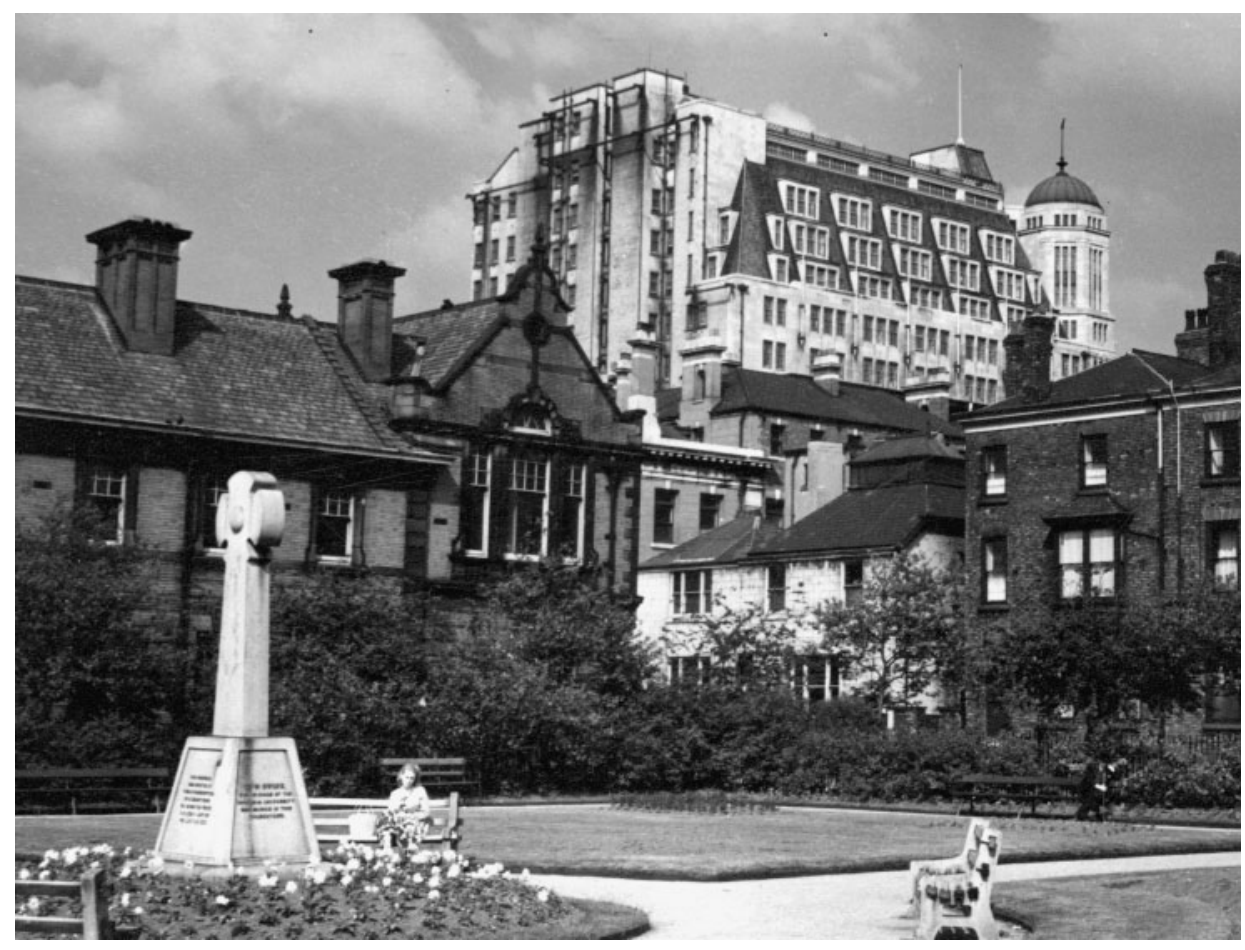

FIGURE 3 St John's Park, Manchester, 1931 (C) Courtesy of Manchester Libraries, Information and Archives

Many of the landscapes acquired by local authorities during the early decades of the twentieth century were not as carefully designed and planned as the early parks had been. Cardiff Corporation was given the 42 acres of Plymouth Wood by the Earl of Plymouth in 1923, which was kept as woodland with the addition of a few pathways. ${ }^{67}$ These wilder landscapes were identified as more "natural" than planned and designed parks. The Western Mail, in its account of the opening of Plymouth Wood, stressed the "natural beauties" of the wood and that the new park's visitors were now "part owners with other citizens." 68 Such landscapes were also less expensive to establish and maintain in the longer term as their wild nature was believed to be both an advantage and an attraction for visitors.

New influences such as city and urban planning also began to have an impact on how parks were perceived in relation to the wider cityscape. There was a movement in the I930s to remove park railings and gates and to thereby integrate the landscape of the urban park more firmly into that of the city. Instead of representing a space in contrast to the urban landscape as the Victorian park had done, the early twentieth century park sought to become incorporated into the wider cityscape. This had the effect of de-emphasising the unique qualities of the urban park and of limiting its citizenship-forming potential. 
In part, this was an extension of the influence of the garden city movement but one which sought to open up parkland vistas and to reflect and accommodate the new urban characteristic of commuting. ${ }^{69}$ Many cities built parkways - arterial roads that linked city and commercial centres with suburbs and residential areas. Manchester's Princess Parkway opened in 1932. Planned and designed by Barry Parker, with the involvement of William Pettigrew, this road to the garden suburb of Wythenshawe, further facilitated the integration of city and parkland, as it bypassed the 6o-acre Alexandra Park. ${ }^{70}$

The intention of the Parkway was to create vistas leading off from the road in different directions and to use such roads to awaken the interest of the public in nature. The road was designed to have land and footpaths on both sides, which were planted with trees and shrubs in an echo of the nearby parkland. This enabled the consumption of leisure spaces beyond the physical boundary of the park and provided the opportunity for the aesthetic enjoyment of green spaces for those in transit through them. At the opening ceremony of the Parkway, the Minister for Transport, P.J. Pybus, suggested that such roads were "a mere canvas on which the citizens are to paint their own gardens," an interesting comment that again reflects the hope that citizens could and would make the urban landscape their own. ${ }^{7 \mathrm{I}}$

This development also emphasises the break with the Victorian park, which was intended to be a contrast to the surrounding cityscape. Now, the citizen was expected to be able to make their own use of the park according to their interests and their circumstances. Therefore, municipal parks had, in practice, returned to the Victorian ideal of the people's park, capable of offering a multiplicity of attractions to a wider public and less narrowly focused on education and citizenbuilding.

However, urban parks were beginning to struggle for the attention of an increasingly sophisticated and demanding leisure consumer. The increasing popularity of the day trip out of the city was providing an opportunity for people to escape the urban environment into the fresh air of the country or seaside resort. The motor car and the expanding rail network as well as the Clarion cycling clubs (in existence since I 895) brought such trips within the reach of many and resulted in the abandonment of public parks by many in favour of the attractions of a more rural or seaside environment. The development of coastal resorts at Bournemouth, Eastbourne and Blackpool lured the leisure-hungry citizen away from the park and the city proper. ${ }^{72}$ Clearly, these activities were only possible for the middle classes (although not exclusively), leaving the urban poor behind to try to take advantage of the municipal facilities, where they could afford to do so. ${ }^{73}$ The ability to leave the city behind was an important sign of the capacity and desire to consume this new form of leisure. The voluntary removal of many middle-class families from the environment of the urban park is ironic when one considers that they were the main beneficiaries in practice of the "rational recreation" of the Victorian period.

By the I930s, however, moves had also begun to extricate children and young people from the city on a regular basis. ${ }^{74}$ This was prompted by an increasing belief that cities were unhealthy places, especially for the children of the urban poor. Opportunities to leave the urban environment were increasing and many charitable organisations were established to take advantage of the perceived 
benefits of day trips to the country or seaside. Some municipal parks offered similar benefits, such as summer camps for disadvantaged children but, increasingly, the impetus was turning away from the urban environment altogether.

\section{Conclusion}

The twentieth century municipal park offered both continuity and a breach with its Victorian forebear. Clearly, there was not an abrupt transition from the Victorian attitude to the Edwardian and later approaches, but rather a gradual repositioning of thought. Much of this occurred at the level of the municipal authorities. The city was increasingly conceived of as a social body whose future prosperity depended on the health of each component part. New powers to legislate at a local level gave the municipality a degree of autonomy over their own affairs but also encouraged a more proactive approach to city management.

This more professional parks management coupled with an increasing appetite for consuming commercial leisure of all kinds resulted in the kinds of tensions outlined here between recreation and entertainment. While many municipal facilities supplied the "basic equipment of urban life," the city took on an increasingly active role and responsibility for all of its citizens. ${ }^{75}$ However, it was also the case that the individual took on a more active role in their city. Their leisure choices determined the supply and cost of recreation facilities and, with increasing amounts of free time and paid holidays, the leisure consumer found themselves with more choices to make from both municipal and private providers. This led to an elision between recreation and entertainment and the municipal conflicts outlined above.

The slow decline of the British municipal park from the end of the Second World War onwards was begun with the damage inflicted on many parks by their military usage. This situation continued post-war, with the primacy of the motor car and the new appeal of television, both of which provided alternative and more desirable forms of entertainment. The extension of the remit of the public park into the arena of popular entertainment was not wholly successful. It may have been successful in drawing new visitors to these spaces (the lack of official and verifiable figures for this remains a frustration) but they were visitors with more temporary appetites and ones whose natural inclination was to seek out oftentransient pleasures. While many of these park visitors had gone "recreation mad" in Nield's words, they had also become victims of the variety and abundance of leisure possibilities now on offer in the twentieth-century city.

There has been an over-emphasis on the Victorian park in academic literature at the expense of later, twentieth-century advances, and too much prominence given to the impact of rational recreation and social control, which offer a limited view of the actual usage of parks. ${ }^{76}$ The concept of rational recreation does not allow for unintended uses made of these parks for meetings and games and offers no prospect of the visitor's individual enjoyment of the space. While twentiethcentury public parks were an evolution of those that originated in the Victorian 
period, they also developed their own character and established new ways for some people to spend their increasing amounts of leisure time.

In attempting to cater for the twentieth-century appetite for recreation, Britain's municipal public parks had sought to meet the challenges of the new century and to adapt themselves to a rapidly changing urban landscape. However, they were not capable of competing with developments in private entertainment provision and with a population that was demanding a greater variety of leisure pursuits. Public parks were now merely one element in a broad landscape of urban recreational possibilities and many were about to lose their distinctive character as a result.

\section{Notes}

I Robert Graves and Alan Hodge, The Long Weekend: A Social History of Great Britain (London, I94I), I03.

2 Carole O'Reilly, "From 'the People' to 'the Citizen': the Emergence of the Edwardian Municipal Park in Manchester I902-I9I2', Urban History, 40, I (20I3), I36-I 55.

3 Brad Beaven and John Griffiths, "Creating the Exemplary Citizen: The Changing Notion of Citizenship in Britain I870-1939", Contemporary British History, 22 (2008), 203-225.

4 Ann B. Rodrick, Self-Help and Civic Culture: Citizenship in Victorian Birmingham (Aldershot, 2004), 67.

5 Michael Stedman, Manchester Pals (Barnsley, 2004), 27.

6 Hugh Cunningham, Leisure in the Industrial Revolution (London, I980), I32.

7 A.A. Pettigrew, The Public Parks and Recreation Grounds of Cardiff, 6 (Cardiff, I932), 53.

8 Rodrick, Self-Help, I 5 .

9 Katy Layton-Jones and Robert Lee, Places of Health and Amusement: Liverpool's Historic Parks and Gardens (Swindon, 2008), 24.

ro Layton-Jones and Lee, Places of Health, 26.

II M. Miller, Raymond Unwin: Garden Cities and Town Planning (Leicester,I992), I89.

I2 F.J. Holmes, "Green Girdles Round Great Cities”, The Quiver, (January I902), 192.

I3 Mirela Altic, "The Formation of Promenades and Parks in Zagreb as part of European Cultural Exchanges", conference paper presented at European Association for Urban History conference, University of Ghent, 20I0, 6.

${ }^{1} 4$ Alan Kidd, Manchester $3^{\text {rd }}$ edition (Edinburgh, 2002), $22 \mathrm{I}$.
I5 Standish Meacham, "Raymond Unwin I863I940: Designing for Democracy in Edwardian England", in Susan Pedersen and Peter Mandler (eds), After the Victorians: Private Conscience and Public Duty in Modern Britain (London and New York, I994), 79-I04, (79).

I6 Meacham, "Unwin", 93.

${ }^{17}$ Elizabeth Davey, "A Complete and Constant Superintendence: The Cheshire Parks and Gardens of Edward Kemp", Cheshire History, 50 (20IO-20II), 7I-IOI, (88, 92).

I8 Manchester City News, 28 December I928, I2.

I9 Josie Harris, Private Lives, Public Spirit: A Social History of Britain (Oxford, I993), I93, 250.

20

${ }^{21}$ Allen Warren, "Sir Robert Baden-Powell, the Scout Movement and Citizen Training in Great Britain 1900-1920”, The English Historical Review, IоI (I986), 376-398.

22 Richard Dagger, "Metropolis, Memory and Citizenship", American Journal of Political Science, (25) I98I, 7I 5-737.

23 West Yorkshire Archive Service (WYAS), Leeds, Leeds Parks committee minutes, LCC $47 / \mathrm{I} / \mathrm{I}$, I904-I910, I6.

24 Pettigrew, Cardiff (5), 40 passim.

25 AJ Allsop, The Official Handbook to the Public Parks of Leeds and Kirkstall Abbey (Leeds, I906), 2 I 5 .

26 Cranz, Women, 82.

27 Claire Langhamer, "Leisure, Pleasure and Courtship: Young Women in England 1920I960" in Mary Jo Maynes, Birgitte Soland and Christina Benninghaus (eds), Secret Gardens, Satanic Mills: Placing Girls in European History I750-I960 (Bloomington, 2005), 272. 
28 Manchester Archives (hereafter MA), Parks and Cemeteries committee minutes, 35, 224.

29 MA, Parks, 35, 224.

$3 \circ$ MA, Parks, 35, 224.

$3^{I}$ WYAS, Leeds, Leeds Parks committee minutes, LCC47/I/2, I9IO-I9I7, I65.

32 Pettigrew, Cardiff (6), 6.

33 Manchester Evening News, I 8 March I926, 7.

34 Pettigrew, Cardiff (2), 65.

35 Manchester City Council blue books, I908I9I3.

${ }^{6}$ W.W. Pettigrew, Municipal Parks: Layout, Management and Administration (London, I932), IOI.

37 J.J. Nott, Music for the People: Popular Music and Dance in Inter-war Britain (Oxford, 2002), 4.

$3^{8}$ Leeds Town Topics: The Leeds and Yorkshire Amusement Programme, March 26 I9ro.

39 MA, Parks and Cemeteries committee minutes, 40, I 8 .

$4 \circ \mathrm{MA}, 40,3$.

4I Hazel Conway, People's Parks: The Design and Development of Victorian Parks in Britain (Cambridge, I99I), I3I.

${ }^{42}$ Kelvingrove Park Heritage Trail. Glasgow: Glasgow City Council, 2007, I6.

43 MA, Parks and Cemeteries committee minutes, 44, 3 I.

44 Manchester Guardian, I2 May I935, 6.

45 Pettigrew, Cardiff (4), I 2.

46 Public Health Act (I925), section 56.

47 Theatrical Managers' Association archive (TMA), Minute book, I927-I936, I83.

$4^{8}$ TMA, Minute book, I927-I936, I I 5 .

49 Pettigrew, Cardiff (6), 8I passim.

5० TMA, Minute book, I927-I936, 344

$5^{I}$ TMA, Minute book, I927-I936, 347.

52 TMA, Minute book, I927-I936, 360.

53 TMA, Minute book, I927-I936, 36I.

54 TMA, Minute book, I928-I936, 2 I3.
55 TMA, Minute book, I927-I936, 289.

56 TMA, Minute book I920-I928, 2 I9.

57 Public Health Act, I925, section 69.

${ }^{8}$ Ina Zweiniger-Bargielowska, Managing the Body: Beauty, Health and Fitness in Britain I880-I939 (Oxford, 2010), 5.

59 Manchester Guardian, I 5 July I926, I 2.

60 Manchester Guardian, 25 February I936, 8.

6I Andrzej Olechnowicz, "Civic Leadership and Education for Democracy", Contemporary British History, I4 (2000), I3.

62 Pettigrew, Cardiff (5), Io6.

63 Pettigrew, Cardiff (5), 44.

64 Pettigrew, Cardiff (5), 86.

65 Municipal Journal, I9 January I934.

66 Layton-Jones and Lee, Places, 59-6I.

67 Pettigrew, Cardiff (5), 48-58.

68 Western Mail, 2 May 1923.

69 Hazel Conway, "Everyday Landscapes: Public Parks from I930 to 2000", Garden History, 28 (200I), II7-I34, (I22).

70 MJP, "Princess Parkway", Journal of the Manchester Parks and Cemeteries Staff Society, 6 (I93 I-I932), 3I-33.

${ }^{71}$ Manchester Evening News, I February I932, 6.

72 John Walton, The English Seaside Resort: A Social History I750-I9I4 (Leicester, I983), 40-4I.

73 Walton, English Seaside, 2I3-2I4.

74 David Pomfret, "The City of Evil and the Great Outdoors: the Modern Health Movement and the Urban Young I918-1940", Urban History, 28 (200I), 405-427.

75 Helen Meller, Leisure and the Changing City I870-I9I4 (London, I976), 99.

76 Conway, People"s Parks; Hilary Taylor, "Public Urban Parks I840-I900: Design and Meaning”, Garden History, 23 (2) (I995), 20I-2I; Teresa Wyborn, "Parks for the People: The Development of Public Parks in Manchester", Manchester Region History Review, IX (I995), 3-I4. 